\title{
WRITS OF ERROR AND APPEALS FROM THE NEW TERRITORIAL COURTS.
}

The extension of the civil government of the United States over the new insular possessions has been attended by many difficult legal questions, the discussion of which in the "Insular Cases," and others of like character, in the United States Supreme Court, has attracted much attention. Besides the vital questions of constitutional law and jurisprudence-such as the distance at which the Constitution, in whole or in part, "follows the flag,"there are others, technical, but important, relating to the procedure necessary to bring the cases before the Supreme Court.

The importance of these technical questions is emphasized by the fact that the maxim "boni judicis est ampliare jurisdictionem" does not appear always to commend itself to the United States Supreme Court, which at times shows a tendency to construe most strictly the statutes by which its jurisdiction and procedure are regulated, so as to avoid jurisdiction if possible. This tendency finds expression in decisions dismissing appeals without passing on themerits, because the proper remedy is held to have been writ of error, and vice versa.

The purpose of this discussion is to outline briefly the procedure necessary to invoke the appellate jurisdiction of the U. S. Supreme Court in cases coming up from Porto Rico, from Hawaii, and from the Philippines. As might be expected from the haphazard and unscientific character of American legislation, there is an entirely different system of appellate procedure for each of these three new possessions.

Porto Rico has the simplest system, and presents few questions. The statute on the subject provides for territorial courts, and for a United States District Court having also the usual jurisdiction of a Circuit Court. The United States -Supreme Court has appellate jurisdiction over both the Territorial Supreme Court and the United States District Court, in the same cases and under the same procedure as over the Supreme Courts of the regular Territories (sec. 35 of the Foraker Act, $3^{\text {I }}$ U. S. Stat. 85). The rule for such territorial appeals is simple and well established. There the remedy is by writ of error "in cases of trial by jury," and "in all other cases by appeal," on a statement of facts in the nature of a special verdict (18 U. S. 
Stat. 27).* With this plain test there can be little difficulty in determining upon the proper remedy in any given case. There is no review by the Circuit Court of Appeals in any event (Royal Ins. Co. v. Martin, 192 U. S. 149; Armado v. U. S. 195 U. S. I72).

Hawaii presents a different and more complicated system of judicial review. The statute provides, as in the case of Porto Rico, both for territorial courts and a United States District Court, having also the jurisdiction of a Circuit Court. The judgments of this District Court are reviewable in the Circuit Court of Appeals for the Ninth Circuit on writ of error or appeal, in the same manner as those of other United States District Courts. The judgments of the highest territorial court are reviewable in the United States Supreme Court on writ of error only, and in cases in which such a writ would lie to the highest court of a State (3x U. S. Stat. 158 , Sec. 86, Ex parte.Wilder's Steamship Co. $18_{3}$ U. S. 545).

An appeal or writ of error may be taken from the United States District Court of Hawaii direct to the United States Supreme Court, if the case involves questions which would allow such review of the determination of a United States District or Circuit Court in one of the States (Hazvaii v. Mankichi, rgo U. S. x97). In such a case the Circuit Court of Appeals has no jurisdiction (Wright v. MacFarlane \& Co. 122 Fed. Rep. 770).

Porto Rico is thus assimilated to a Territory and Hawaii to a State, in matters of appellate procedure.

In the Philippines there are no strictly Federal Courts, but a Supreme Court continued by act of Congress with general jurisdiction, both legal and equitable. The statute which gives an appeal from this court provides that its final judgments and decrees in causes involving "the Constitution or any statute, treaty, title, right or privilege of the United States," or an amount or value of more than $\$ 25,000$, may be reviewed by the United States Supreme Court "on appeal or writ of error by the party aggrieved, in the same manner, under the same regulations, and by the same procedure, as far as applicable, as the final judgments and decrees of the circuit courts of the United States" (U. S. Stat. Vol. 32, Part I, p. 695, Sec. 10).

* Oklahoma is an exception to this rule. The judgments of its highest court are reviewable in the same manner as those of a U. S. Circuit Court, and a writ of error must be employed in actions at law, even if there has not been a jury trial. 26 U. S. Stat. 81; Comstock v. Eagletor, I96 U. S. 99. 
This would seem to leave the procedure sufficiently elastic to enable the United States Supreme Court to take jurisdiction in all such cases where the method used to bring the cause before it is not manifestly inappropriate and erroneous. Yet there have been already several dismissals because a writ of error was used instead of an appeal, or vice versa, in cases where the question was, to say the least, a close one, and where the court could have assumed jurisdiction without contravening any express statute or settled rule of law.

In Behn, Meyer \& Co. v. Campbell, 200 U. S. 6Ir, the action was in the nature of assumpsit, and the appeal was dismissed for the want of jurisdiction, upon the authority of cases holding that judgments in such actions in United States Circuit Courts were reviewable by writ of error only. On the other hand, in the Barcelon habeas corpus case (Fisher v. Baker 203 U.S. r74), a writ of error to review an order dismissing a petition for habeas corpus, on the ground that the privilege of the writ had been suspended, was dismissed on the ground that such orders were reviewable only by appeal. Very grave constitutional questions were involved in this case and were elaborately argued at the bar. The decision was put upon the authority of certain prior decisions cited by the court holding that in the United States Circuit Courts, habeas corpus proceedings were properly reviewable by appeal under the statutes relating thereto. There had been, however, no prior decisions holding that where only questions of law were to be presented, a writ of error would not lie, and in fact such writ is necessarily used in reviewing habeas corpus proceedings in the State courts. (See Tinsley v. Anderson, 17I U: S. 101, Hatch v. Reardon, 204 U. S.-).

In reviewing judgements of the United States Circuit Courts the question is comparatively simple. Judgments at law and in criminal causes are reviewable by writ of error; decrees in equity and admiralty are reviewable by appeal; habeas corpus proceedings, it is now settled, are likewise reviewable by appeal; and any other special statutory proceedings in such manner as may be provided by-the statutes regulating them. But the jurisdiction of the United States Circuit Courts by no means covers the whole field of jurisprudence. These courts have no jurisdiction over matters of probate and administration; marriage and divorce; incompetency and guardianship; adoption and filiation -all of which would or might come within the jurisdiction of the Philippine courts, and in a proper case, be reviewable by the United States Supreme Court. The question is made still more 
difficult by the complicated structure of Philippine law, which consists of a basis of Civil Law with an overlying layer of American Statutes enacted by Congress and by the Philippine Commission, contributing elements of "Common Law" jurisprudence and procedure. The two systems are so different-in some respects so inconsistent-that it is often very difficult to determine to what category, according to American legal terminology, a given action or proceeding belongs, in order to decide which of the two methods of review to adopt.

In theory, and in their historical development, the two methods are easily differentiated. An appeal is addressed by the defeated party to the court below, which issues its citation to the other party to appear in the appellate tribunal, and sends up to that tribunal the whole record with all the testimony. The whole case is presented to the appellate tribunal for review upon both the law and the facts (Wiscart $v$. d'Auchy, 3 Dallas 321 ; Johnson v. Harmon, 94 U. S. 37I). This method of review is taken from the Courts of Chancery and Admiralty, whose procedure so largely follows that of the Civil Law. It is also used, with certain modifications as to the required contents of the record, in States which, like New York, have attempted to abolish the distinction between law and equity, and have adopted a uniform system of procedure, and it would seem eminently appropriate for the appellate jurisdiction over the Philippine courts, with their civil law procedure.

A writ of error, on the other hand, is in theory a mandate from the court above, commanding the court below to send up the record of a cause, so that errors of law, apparent thereon, may be reviewed and corrected. It is addressed to the court and not to the party, and only so much of the record as is necessary for a proper presentation of the question involved is transmitted. It is essentially a common-law remedy and applicable primarily to the review of common-law trials, where all questions of fact are settled conclusively by a jury's verdict, and only pure questions of law remain for review. There is no logical juristic reason, however, why it should not be applicable to any cause of any nature, in which questions of law only are sought to be reviewed, and in fact it was the only method of reviewing in the United States Supreme Court the judgments and decrees of the lower federal courts until the judiciary amendment of r803. (See I U. S. Stat., 84; 2 U. S. Stat., 244). But law, and particularly the law of procedure, is such a patchwork of decisions 
and statutes, uncorrelated and often inharmonious, that logic has little or nothing to do with it.

It therefore becomes necessary to consider how far the rula of procedure established for the review of United States Circuit Court judgments furnish precedents for the review of Philippine Supreme Court judgments, involving the necessary jurisdictional questions or amount, especially in cases not analocous to any within the Circuit Court jurisdiction. The Behn, Meyer \& Company case may be regarded as settling the rule that all actions in the nature of assumpsit must be reviewed by writ of error. The same rule would doubtless apply to all actions of a strictly common-law character in which judgment for a sum of money only, or for the delivery of a specific chattel or the possession of a specific parcel of real property is demanded. It also applies to criminal prosecutions. (See Dorr v. U. S., r95 U. S. $138 ;$ Keprer v. U. S., 195 U. S. 100; Trono v. U. S., 199 U. S. 52 ).

All suits which, if brought in a Circuit Court, would lie on the equity side, and all proceedings in admiralty, would certainly be reviewable by appeal. The Barcelon case establishes that habeas corpus proceedings are also reviewable by appeal only, and not by writ of error.

The case of De la Rama v. De la Rama, 201 U. S. $3^{\circ 3}$, determines that actions for divorce involving alimony or a division of conjugal property of the jurisdictional amount, are reviewable by appeal. Since the reversal in this case was on a question of fact the court necessarily determined that appeal was the proper method of review. This decision appears to be the first instance in which the United States Supreme Court has ever passed on the facts in a divorce case.

Aside from these few decisions there appear to be no direct precedents to guide the litigant who wishes to have a Philippine judgment reviewed by the United States Supreme Court. The nearest analogy will be found in the decisions upon cases coming up from the District of Columbia, where the practice is also assimilated by statute to that followed in reviewing Circuit Court judgments (sec. 705 U. S. Rev. Stat., 27 U. S. Stat. p. 434), and where the courts, like those of the Philippine Islands, are of plenary, as distinguished from merely federal, jurisdiction.

From this source the following suggestions may be gathered: Final orders granting or refusing probate of a will are reviewable by writ of error. This was held in Ormsby $v$. Webb, x34 U. S. 47. The court said that "a proceeding involving the original probate of bill is not strictly a proceeding in equity," and that "if. 
it be not a case in equity, it is to be brought to this court upon writ of error, although the proceeding may not be technically one at law, as distinguished from equity." In this case there had been a jury trial of certain issues of fact, but the same rule as subsequently applied to a case in which the court had acted without a jury (Campbell v. Porter, 162 U. S. 478 ). In view of the historical development of probate jurisdiction, which originally belonged primarily to the ecclesiastical courts with their civil law jurisprudence and procedure, including appeal as the invariable method of review, the decision in these two cases seems to be an exception to the tendency to avoid jurisdiction.

In other proceedings pertaining to what is usually called probate jurisdiction a different rule is followed, as shown by-the case of Kenaday $v$. Sinnott, 179 U. S. 606. This was a controversy raised by objections to an executor's final account. The court held that this was "in its nature of equitable cognizance," and that the decree was "properly reviewable on appeal rather than on writ of error." The appellant in this case first sued out a writ of error and then obtained the allowance of an appeal. the order reciting "that the practice in cases exactly of the character of the present one has not been established by precedent." The other party moved to dismiss the appeal because of the previous issue of the writ of error, and to dismiss the writ of error because the proper remedy was by appeal. The court denied the first motion and considered the case on the merits, and the second motion thus became of no consequence. A suit for the construction of a will is also reviewable by appeal (Cruit ข. Owen, 203 U. S. 368 ).

The somewhat anomalous result is thus reached that a decree granting or refusing probate of a will can be reviewed on the law only, while a controversy over its construction or over the accounts of its executor may be reviewed on the facts also.

Proceedings for the condemnation of real property have been held to be analogous to an action at law and hence reviewable by writ of error only (Metropolitan R. R. Co. v. District of Columbia,195 U. S. 322). Proceedings by mandamus and prohibition are also deemed to be at law and are therefore reviewable by writ of error (Steinmetz v. Allen, 192 U. S. 543 ; Lowry v. Allen, 203 U. S. 476 ; Smith v. Whitney, 116 U. S. 167).

If trial by jury is ever introduced into the Philippines the ruling in the cases of Elliott $v$. Toeppner, 187 U. S. 327 , and Grant Shoe Co. v. Laird Co., 203 U. S. 502, will doubtless apply, namely, that even in bankruptcy proceedings, if a trial by jury 
is had as a matter of right, it must be regarded as " a trial according to the course of the common law," and the judgment thereon "revisable only on writ of error."

From the cases examined the following tentative classification may be made of the proper remedies to obtain a review of Philippine judgments and decrees subject to the appellate jurisdiction of the United States Supreme Court by reason of finality and of the questions or amount involved.

Proceedings analogous to ordinary) civil actions at law.

Criminal prosecutions.

Condemnation proceedings.

Writ of error.

Proceedings by mandamus and prohibition.

Proceedings to prove a will.

Suits of an equitable nature.

Matrimonial actions.

Accountings in courts of probate jurisdiction.

Habeas corpus proceedings.

Proceedings in admiralty.

Proceedings in bankruptcy

(without jury trial).

In all cases where there is any uncertainty, the course followed in Kenaday v. Sinnott (supra) may be adopted, and both remedies used. In such a case it would be a wise precaution to take an order allowing the appeal and reciting the uncertainty, and also to have a record so made up as to be sufficient under either form of review; that is to say, containing all the evidence to allow full review upon the appeal, and also a proper bill of exceptions, duly allowed by the trial judge, to present such questions as may be raised upon the writ of error.

Doubtless in time precedents will be created which will cover most of the categories of legal proceedings and establish rules of procedure approximately certain until disturbed by further legislation.

It would seem that Congress might easily have established some test, appropriate to the prevailing procedure in the Philippines, and as simple as that applied to ordinary territorial appeals, or might have provided for a uniform method of 
review, by writ of error in all cases, as in the early days of the Supreme Court, or by appeal in all cases, with such limitations as to the return of evidence and review of facts as might be deemed advisable. But Congress has not done so, and the system must now be worked out at the expense of those litigants whose counsel are not fortunate enough to foresee the United States Supreme Court's decision as to the particular category, under one system of legal terminology, to which to assign a. given proceeding under a totally different system.

Howard Thayer Kingsbury.

Fibruary, 1907. 